\title{
Evaluation and comparison of alpha- and beta-amanitin toxicity on MCF-7 cell line
}

\author{
Ertuğrul KAYA ${ }^{1}$, Recep BAYRAM ${ }^{2}$, Kürşat Oğuz YAYKAŞLI ${ }^{3, \star}$, İsmail YILMAZ $^{4}$, Sait BAYRAM ${ }^{1}$, \\ Emine YAYKASSLI ${ }^{5}$, Muhsine Zeynep YAVUZ ${ }^{2}$, Ali Akçahan GEPDİREMEN ${ }^{2}$ \\ ${ }^{1}$ Department of Medical Pharmacology, Faculty of Medicine, Düzce University, Düzce, Turkey \\ ${ }^{2}$ Department of Medical Pharmacology, Faculty of Medicine, Abant İzzet Baysal University, Bolu, Turkey \\ ${ }^{3}$ Department of Medical Genetics, Faculty of Medicine, Düzce University, Düzce, Turkey \\ ${ }^{4}$ Department of Medical Pharmacology, İzmir Bozyaka Training and Research Hospital, İzmir, Turkey \\ ${ }^{5}$ Department of Medical Biology and Genetic, Institute of Health Science, Düzce University, Düzce, Turkey
}

\begin{tabular}{lllllll}
\hline Received: 13.09 .2013 & $\bullet$ & Accepted: 09.12 .2013 & $\bullet$ & Published Online: 15.08 .2014 & $\bullet$ & Printed: 12.09 .2014 \\
\hline
\end{tabular}

Background/aim: Alpha- and beta-amanitins are the main toxins of the poisonous Amanita phalloides mushroom. Although there are many studies available concerning alpha-amanitin, there are limited data about beta-amanitin in the literature. Therefore, this study is aimed at comparing the toxic effects of alpha- and beta-amanitin on the MCF-7 cell line.

Materials and methods: The alpha- and beta-amanitins used for this research were purified from Amanita phalloides by preparative high-performance liquid chromatography. The MCF-7 breast cancer cell line was used, and specific concentrations of the toxins (100, $10,1,0.1$, and $0.01 \mu \mathrm{g} / \mathrm{mL}$ ) were applied to the cells. The MTT test was performed to determine the level of toxicity, and the quantity of protein in the cell was measured using the biuret test.

Results: The alpha-amanitin showed a higher toxicity at $36 \mathrm{~h}$, while the highest inhibition of protein synthesis by the beta-amanitin was observed at $24 \mathrm{~h}$.

Conclusion: It was shown that the beta-amanitin may be responsible for toxicity, like alpha-amanitin, in Amanita phalloides mushroom poisoning. The early inhibition of protein synthesis for beta-amanitin might be useful for future experiments and research.

Key words: Alpha-amanitin, beta-amanitin, MCF-7 cell line, mycotoxins

\section{Introduction}

Deaths from mushroom poisoning, due to the ingestion of mushrooms containing amatoxins, seem to be increasing both in Turkey and worldwide (1). The alpha-amanitin (a-AMA) found in Amanita phalloides (also called the death cap mushroom) is one of the most toxic agents, and it is responsible for more than $90 \%$ of the cases of deadly mushroom poisoning (2). The oral $50 \%$ lethal dose $\left(\mathrm{LD}_{50}\right)$ of $\alpha$-AMA is $0.1 \mathrm{mg} / \mathrm{kg}$ for mice, and a single mushroom can contain a fatal dose (10-12 mg) large enough for a human (3). In addition to $\alpha$-AMA, several amatoxins, including beta amanitin ( $\beta$-AMA), gamma-amanitin, amanullin, and amanullinic acid, have been identified in this mushroom (4).

Amatoxins are also known as cyclopeptides because they consist of 8 amino acids in a circular chain. The sulfur atom in the cysteine amino acid converts the structure from the cyclic to bicyclic form by bonding with the indolamine group in the amino acid tryptophan. The tryptathionine

*Correspondence: kursatyay@yahoo.com moiety and bicyclic structure of the amatoxins are mainly responsible for toxicity, and the toxin diversity in the mushroom emerges from the chemical changes in the main structure $(5,6)$. The quantities of $\alpha$-AMA and $\beta$-AMA are similar, and these toxins have been found more commonly than any other toxins in the mushrooms $(7,8)$. The $\alpha$-AMA and $\beta$-AMA have similar structures, except in the R substituent. $\alpha$-AMA contains an amino group and is neutral, while $\beta$-AMA contains carboxyl and is acidic (9). Amatoxins are heat-stable octapeptides, and it has been demonstrated that the stability of a-AMA in water and methanol is maintained at different temperatures, even after 6 months $(10,11)$.

The uptake of amanitin into hepatocytes is mediated by a transport system $(12,13)$. While it does not show a direct cytolytic effect, it inhibits eukaryotic RNA polymerase II. In this way, a-AMA causes cell death by inhibiting the transcription of DNA and protein synthesis (14-16). The damage to the liver and kidneys caused by $a$-AMA depends 
on the received dose. The mortality rate after digestion is very high, and irreversible liver failure may result in death within 3 to 7 days (17).

In vitro and in vivo investigations have demonstrated that a-AMA may cause apoptotic cell death as well as hepatocyte necrosis. Experiments performed on canine hepatocyte cultures have shown that apoptosis plays a vital role in the pathogenesis of hepatic damage caused by $\alpha$-AMA intoxication $(2,18)$. The $\alpha$-AMA-induced apoptosis is associated with severe liver damage, especially in the early stages of poisoning (18); however, a nonlethal dose of a-AMA prevents DD1 (a novel death domain)mediated apoptosis by disrupting the protein synthesis. In fact, this process is under investigation in cell culture experiments either alone or in combination with other medicines for the treatment of cancer (19-21). The cytotoxic effect of $\beta$-AMA has been shown in a few studies, but the stability of $\beta$-AMA has not been investigated in detail (22-24).

There are several papers related to the toxicity of a-AMA, but there are no studies investigating both $\alpha$-AMA and $\beta$-AMA toxicity. In the present study, the evaluation and the comparison of $\alpha$-AMA and $\beta$-AMA toxicity on the MCF-7 cell line were conducted.

\section{Materials and methods}

From Amanita phalloides, $\alpha$-AMA and $\beta$-AMA were isolated with $>99 \%$ purity using a preparative highperformance liquid chromatography (HPLC) method and were quantified using an analytical HPLC method, as described previously. The mushrooms were classified systematically based on their microscopic and macroscopic characteristics, were dried under flowing air at $50{ }^{\circ} \mathrm{C}$ for 12 $\mathrm{h}$, and were crushed. The extracts were prepared in $50 \%$ methanol, and they were applied to the preparative HPLC system twice. The fractions of $\alpha$-AMA and $\beta$-AMA were collected according to their retention time, and the purity of the toxins was confirmed using the analytical HPLC system. The obtained toxin's purity was higher than $99 \%$ $(25,26)$.

The human breast cancer cell line, MCF-7, was obtained from the American Type Culture Collection. Dulbecco's Modified Eagle Medium (Invitrogen, USA) and fetal bovine serum (Invitrogen) were used as the medium and serum, respectively. The MCF-7 cells were incubated in $5 \% \mathrm{CO}_{2}$ at $37^{\circ} \mathrm{C}$, and the toxins were applied to the cell culture medium at $100,10,1,0.1$, and $0.01 \mu \mathrm{g} / \mathrm{mL}$ final concentrations after being dissolved in water and were incubated for specific time periods.

\subsection{Determination of cell viability}

The MTT assay [3-(4,5-dimethylthiazol-2-yl)-2,5diphenyltetrazolium bromide] was used to evaluate the overall functional integrity and viability of the cultured cells (17). The MCF-7 cells were put into 96-well plates (2 $\times 10^{4}$ for each well), which were incubated for $24 \mathrm{~h}$. The specific concentrations of $\alpha$-AMA and $\beta$-AMA were added to the cell culture medium, and plates were incubated for an additional $36 \mathrm{~h}$. MTT solution (1:10 ratio) and dimethyl sulfoxide (DMSO) $(100 \mu \mathrm{L})$ were then added to the cell culture medium and plates were incubated overnight. The absorbance was measured at $570 \mathrm{~nm}$ on a plate reader. This experiment was repeated 3 times. The absorbance data were calculated as percentages according to the control group.

\subsection{Measurement of the total protein}

The total protein was measured using the biuret test (27). After harvesting the MCF-7 cells, the lysis buffer (Caspase-3 Colorimetric Kit, Invitrogen) was added to the cell pellet, which was chilled on ice for $10 \mathrm{~min}$. The samples and separate concentrations $(0,1,2,4,8,16$, and $32 \mathrm{mg} /$ $\mathrm{mL}$ ) of bovine serum albumin were added to 96-well plates, and $90 \mu \mathrm{L}$ of biuret solution was added to each well. The samples were then incubated at room temperature for $15 \mathrm{~min}$. The absorbance was measured at $570 \mathrm{~nm}$ on an ELISA reader, and the total protein concentrations for the samples were calculated according to the calibration graph. This experiment was repeated 3 times.

\subsection{Statistical analysis}

Statistical analyses were performed using PASW 18 statistical software (ver. 18.0 for Windows; SPSS Inc., USA), and the data were analyzed using 2-factor ANOVA and Tukey's tests. The level of statistical significance was set at $\mathrm{P}<0.05$.

\section{Results}

\section{1. $\alpha$-AMA showed more toxicity than $\beta$-AMA}

According to the MTT test data, $\alpha$-AMA decreased cell viability by $14 \%, 21 \%, 41 \%, 44 \%$, and $50 \%$ at concentrations of $100,10,1,0.1$, and $0.01 \mu \mathrm{g} / \mathrm{mL}$, respectively. The $\mathrm{LD}_{50}$ of the a-AMA at $36 \mathrm{~h}$ was measured as $1 \mu \mathrm{g} / \mathrm{mL}$, and statistical significance was obtained in terms of cell death at this dose and higher doses $(\mathrm{P}<0.05)$. Similarly, the rates of cell viability were calculated as $52 \%, 62 \%, 84 \%, 86 \%$, and $91 \%$ at concentrations of $100,10,1,0.1$, and $0.01 \mu \mathrm{g} / \mathrm{mL}$, respectively, for the $\beta$-AMA. The $\mathrm{LD}_{50}$ of the $\beta$-AMA at 36 $\mathrm{h}$ was measured as $10 \mu \mathrm{g} / \mathrm{mL}$, and statistical significance was obtained in terms of cell death at this dose and higher doses $(\mathrm{P}<0.05)$ (Figure 1$)$. The $\alpha$-AMA showed greater toxicity than the $\beta$-AMA at $36 \mathrm{~h}$.

\section{2. $\beta$-AMA inhibits the protein synthesis earlier than a-AMA}

The $\beta$-AMA showed a greater inhibition of protein synthesis at both concentrations $(10 \mu \mathrm{g} / \mathrm{mL}$ and $1 \mu \mathrm{g} / \mathrm{mL})$ for $24 \mathrm{~h}(\mathrm{P}<0.05)$. The total amount of protein within the cell at $24 \mathrm{~h}$ was significantly increased for the $1 \mu \mathrm{g} /$ 


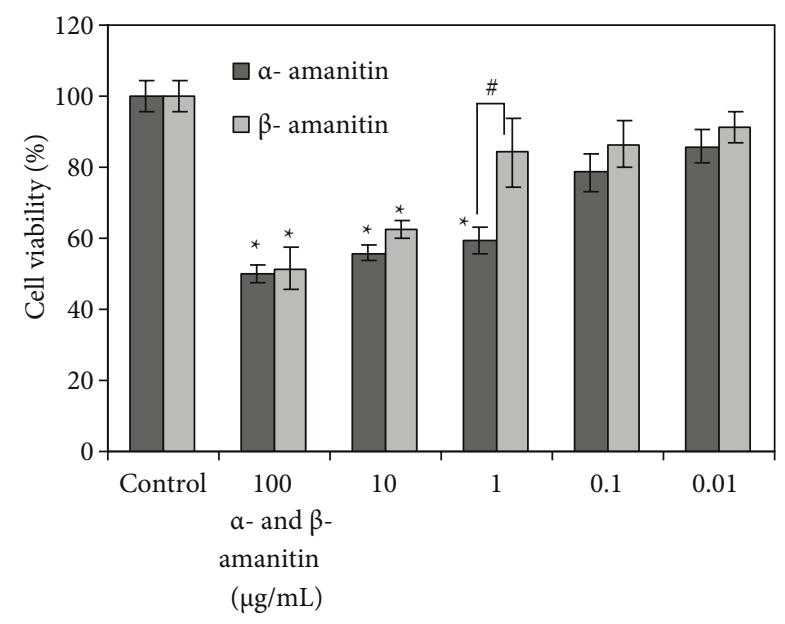

Figure 1. The rate of cell viability after toxin treatment. The cell line was stimulated by $\alpha$ - and $\beta$-amanitin at certain concentrations. After incubation for $36 \mathrm{~h}$, the MTT test was performed to evaluate the cell viability $\left({ }^{*}\right.$ : statistical difference between toxin and control groups, \#: statistical difference between $\alpha$ - and $\beta$-amanitin groups).

$\mathrm{mL}$ dose of $\alpha$-AMA compared to the control $(\mathrm{P}<0.05)$. In contrast, the total amount of protein within the cell at $24 \mathrm{~h}$ was significantly decreased for the $10 \mu \mathrm{g} / \mathrm{mL}$ dose of $\beta$-AMA when compared to the control $(\mathrm{P}<0.05)$ (Figure 2).

\section{Discussion}

Cases of mushroom poisoning are most often the result of Amanita phalloides ingestion, with its main toxins being amatoxins. It is assumed that $\alpha$-AMA is the most toxic agent in the mushroom, but the toxicity of $\beta$-AMA is not known in detail. Clarification of this issue may help to develop new emergency treatment methods in cases of mushroom poisoning. In this study, the toxicity of $\alpha$ and $\beta$-AMA were evaluated and compared in the MCF-7 breast cancer cell line.

a-AMA has a hepatotoxic effect, and its uptake into hepatocytes is mediated by a special transport system $(12,13)$. However, it was reported that a-AMA penetrates into tumor cells by receptor-mediated endocytosis (29). To evaluate the purely toxic effects of amatoxins, cell lines other than hepatocytes were used in this investigation. For our purposes, several cell lines, such as MCF-7 (breast cancer) (20), BxPC-3 and CAPAN-1 (human pancreatic carcinoma), Colo205 (colorectal carcinoma), OZ (bile duct carcinoma) (21), A431 (epidermoid carcinoma) (22), and L1210 (lymphocytic leukemia) (23) cells, were considered.

Five different concentrations of toxins were applied to MCF-7 cell lines, and the toxicities were evaluated after 36 h. The data obtained show that the $\mathrm{LD}_{50}$ was $1 \mu \mathrm{g} / \mathrm{mL}$ for

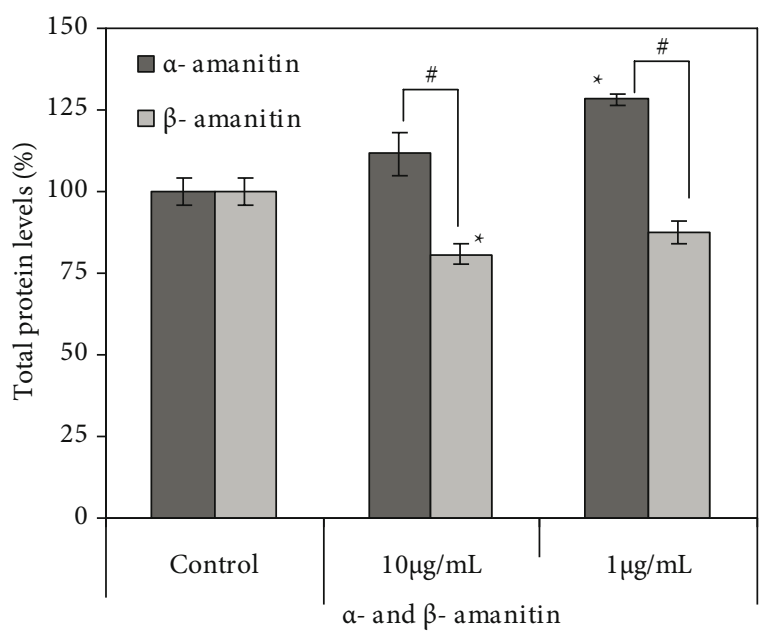

Figure 2. The level of total protein within the cell after toxin treatment. The cell line was stimulated by $\alpha$ - and $\beta$-amanitin at certain concentrations. After incubation for $36 \mathrm{~h}$, the biuret test was performed to determine the protein levels ( ${ }^{*}$ : statistical difference between toxin and control groups, \#: statistical difference between $\alpha$ - and $\beta$-amanitin groups).

$\alpha$-AMA and $10 \mu \mathrm{g} / \mathrm{mL}$ for $\beta$-AMA. Therefore, the toxicity of $\alpha$-AMA is greater than that of $\beta$-AMA. Similar results were obtained in several studies; for example, Magdalan et al. evaluated the toxicity of $\alpha$-AMA in hepatocytes at certain concentrations, and comparable results were obtained from their findings (2). The cytotoxicity of $\beta$-AMA has been investigated in a limited number of studies and was demonstrated in A431 (22) and L1210 lymphocytic leukemia cell lines $(23,24)$. It can be concluded from the literature data that the cytotoxicity increases as the concentration of $\alpha$-AMA increases (13).

The putative mechanisms of $\alpha$-AMA causing toxicity are currently under debate. $\alpha$-AMA does not show a direct cytolytic effect, but it does block DNA transcription by inhibiting the RPB1 subunit of RNA polymerase II, leading to cell death $(15,16)$. Additionally, a-AMA induces both necrotic and apoptotic cell death concomitantly in the hepatocytes, where elevated cellular apoptosis is especially emphasized $(2,18)$. In human fibroblasts and human colon carcinoma cell line 116 (HTC116), a-AMA was shown to induce the accumulation of p53 in the mitochondria, which leads to p53- and caspase-dependent apoptosis $(16,21,30-32)$. The inhibition of apoptosis by a-AMA was also suggested $(19,20)$.

The other mechanism for a-AMA toxicity is its involvement in free radical reactions. An increase in superoxide dismutase activity and decrease in catalase activity after treatment with $\alpha$-AMA was determined by Zheleva et al. Therefore, $\alpha$-AMA has a prooxidative or antioxidant effect, depending on the toxin concentrations 
(33). The roles of oxidative stress in hepatotoxicity and hepatocyte apoptosis have been reported before, and it can be concluded that an increase in the reactive oxygen species level induced by a-AMA probably increases liver toxicity, contributing to hepatocyte membrane damage $(34,35)$. In addition, a-AMA was found to decrease the expression of transcription factor nuclear factor erythroid 2 (NF-E2) related factor 2 (NRF2).

It is well characterized that NRF2 stimulates the antioxidant defense system in response to oxidative stress, and it could be speculated that the decreased expression of NRF2 by a-AMA may be involved in the cytotoxicity of a-AMA (36). Furthermore, tumor necrosis factoralpha aggravates the $\alpha$-AMA cytotoxicity by a mechanism that may involve reactive oxygen species $(37,38)$. There are several putative mechanisms of a-AMA causing toxicity, but these have not been clarified in detail.

$\beta$-AMA inhibited the total protein synthesis more than $\alpha$-AMA at the end of $24 \mathrm{~h}$ after the treatment of the MCF7 cells with the toxins. There may be several reasons for this, but the most plausible reason is that $\beta$-AMA might penetrate into the cells more easily and quickly and begin to inhibit protein synthesis earlier than a-AMA. These amatoxins have a similar structure, and they mainly consist of 8 amino acid residues, arranged in bicyclic octapeptides to form a pentacyclic structure, having 5 different changeable positions. The structural difference between $\alpha$-AMA and $\beta$-AMA is an amino group $\left(\mathrm{NH}_{2}\right)$ at the third position. The $\mathrm{NH}_{2}$ group is present in $\alpha$-AMA, while the hydroxyl $(\mathrm{OH})$ group is present in $\beta$-AMA $(39,40)$. This difference causes the altered pharmacokinetics of the toxins (41).

In addition, a study done by Tinnikov et al. revealed that the penetration of a-AMA into cells is relatively slow and depends on the concentration and cell type

\section{References}

1. Fedakar R, Türkmen N. Fatal poisonings in the South Marmara Region of Turkey. Eur J Gen Med 2008; 5: 1-8.

2. Magdalan J, Ostrowska A, Podhorska-Okołów M, Piotrowska A, Izykowska I, Nowak M, Dolińska-Krajewska B, Zabel M, Szelag A, Dziegiel P. Early morphological and functional alterations in canine hepatocytes due to alpha-amanitin, a major toxin of Amanita phalloides. Arch Toxicol 2009; 83: $55-60$.

3. Wieland T. Peptides of Poisonous Amanita Mushrooms. 1st ed. New York, NY, USA: Springer: 1986.

4. Vetter J. Toxins of Amanita phalloides. Toxicon 1998; 36: 13-24.

5. Little MC, Preston JF. Sensitivity of carrot cell cultures and RNA polymerase II to Amatoxins: Evidence for the inactivation of 6'-hydroxyamatoxins. Plant Physiol 1985; 77: 443-449.
(20). Receptor-mediated endocytosis may be partially responsible for this slow rate (29). These data are consistent with our experimental data. In our experiment, the cells were treated with toxins for $24 \mathrm{~h}$; however, treatment for longer than $24 \mathrm{~h}$ might be needed to clarify the inhibition of protein synthesis in detail. This is a limitation of our study.

The total protein quantity within the cell was decreased in the treatment with $10 \mu \mathrm{g} / \mathrm{mL} \beta$-AMA, but it was increased in the treatment with $1 \mu \mathrm{g} / \mathrm{mL} \alpha$-AMA for $24 \mathrm{~h}$ when compared to the control. This result was not consistent with earlier hepatocyte culture studies (2), and the putative reason may be the cell type. It was also reported that $\alpha$-AMA has antiapoptotic characteristics, which could also be the reason $(19,20)$.

In addition to toxicity, recent studies have showed that amanitins exhibit retardation activity on tumor cells and ectoparasites without affecting somatic cell activity. Therefore, $\alpha$-AMA has the potential for use as a medicine for the therapy of diseases like cancer or ectoparasitic infections $(20,21,42,43)$.

In conclusion, our study is the first to evaluate and compare the cytotoxicity of $\alpha$-AMA and $\beta$-AMA in the same conditions. We concluded that both toxins have cytotoxic effects, but those of a-AMA are a little higher. $\beta$-AMA also has toxic effects in mushroom poisoning, and alternative therapies targeting $\beta$-AMA should be developed in hepatotoxicity investigations. In addition, both toxins have potential uses in new therapy methods for cancer but require further investigation.

\section{Acknowledgment}

This work was supported by the Düzce University Scientific Research Coordinator (DUBAP, 2012.04.03.087).
6. May JP, Fournier P, Patrick BO, Perrin DM. Synthesis, characterisation, and in vitro evaluation of Pro2-Ile3-S-deoxoamaninamide and Pro2-D-allo-Ile3-S-deoxo-amaninamide: implications for structure-activity relationships in amanitin conformation and toxicity. Chemistry 2008; 14: 3410-3417.

7. Kaya E, Karahan S, Hancı M, Yaykaşlı KO, Sarıtaş A, Bayram R, Yilmaz I, Arslan SO. The measurement of alpha amanitin levels using HPLC method in Amanita phalloides from Düzce province. Düzce Tip Dergisi 2012; 14: 15-17 (article in Turkish with English abstract).

8. Robinson-Fuentes VA, Jaime-Sánchez JL, García-Aguilar L, Gómez-Peralta M, Vázquez-Garcidueñas MS, VázquezMarrufo G. Determination of alpha- and beta-amanitin in clinical urine samples by capillary zone electrophoresis. J Pharm Biomed Anal 2008; 47: 913-917. 
9. Schneider SM. Mushrooms. In: Ford MD, Delaney KA, Ling LJ, Erickson WB, editors. Clinical Toxicology. Philadelphia, PA, USA: WB Saunders Company; 2001. pp. 899-909.

10. Kaya E, Hancı M, Karahan S, Bayram S, Yaykaşlı KO, Sürmen MG. Thermostability of alpha amanitin in water and methanol. Eur J Basic Med Sci 2012; 2: 106-111.

11. Kröncke KD, Fricker G, Meier PJ, Gerok W, Wieland T, Kurz G. a-Amanitin uptake into hepatocytes. Identification of hepatic membrane transport systems used by amatoxins. J Biol Chem 1986; 261: 12562-12567.

12. Letschert K, Faulstich H, Keller D, Keppler D. Molecular characterization and inhibition of amanitin uptake into human hepatocytes. Toxicol Sci 2006; 91: 140-149.

13. Tata JR, Hamilton MJO, Shields D. Effects of $\alpha$-amanitin in vivo on RNA polymerase and nuclear RNA synthesis. Nat New Biol 1972; 238: 161-164.

14. Nguyen VT, Giannoni F, Dubois MF, Seo SJ, Vigneron M, Kédinger C, Bensaude O. In vivo degradation of RNA polymerase II largest subunit triggered by alpha-amanitin. Nucleic Acids Res 1996; 24: 2924-2929.

15. Magdalan J, Piotrowska A, Gomułkiewicz A, Sozański T, Podhorska-Okołów M, Szeląg A, Dzięgiel P. Benzylpenicyllin and acetylcysteine protection from $\alpha$-amanitin-induced apoptosis in human hepatocyte cultures. Exp Toxicol Pathol 2011; 63: 311-315.

16. Serene EH, Toorians AWFT, Gietema JA, Bronsveld W, Haagsma EB, Mulder POM. Amanita phalloides, a potentially lethal mushroom: its clinical presentation and therapeutic options. Neth J Med 1996; 49: 19-23.

17. Magdalan J, Ostrowska A, Piotrowska A, Izykowska I, Nowak M, Gomułkiewicz A, Podhorska-Okołów M, Szelag A, Dziegiel P. Alpha-Amanitin induced apoptosis in primary cultured dog hepatocytes. Folia Histochem Cytobiol 2010; 48: 58-62.

18. Terashima J, Yasuhara N, Iwami M, Sakurai S, Sakurai S. Programmed cell death triggered by insect steroid hormone, 20-hydroxyecdysone, in the anterior silk gland of the silkworm, Bombyx mori. Dev Genes Evol 2000; 210: 545-558.

19. Tinnikov AA, Yeung KT, Das S, Samuels HH. Identification of a novel pathway that selectively modulates apoptosis of breast cancer cells. Cancer Res 2009; 69: 1375-1382.

20. Moldenhauer G, Salnikov AV, Lüttgau S, Herr I, Anderl J, Faulstich $\mathrm{H}$. Therapeutic potential of amanitin-conjugated anti-epithelial cell adhesion molecule monoclonal antibody against pancreatic carcinoma. J Natl Cancer Inst 2012; 104: 622-634.

21. Bermbach U, Faulstich H. Epidermal growth factor labeled betaamanitin-poly-L-ornithine: preparation and evidence for specific cytotoxicity. Biochemistry 1990; 29: 6839-6845.

22. Zhelev Z, Ilarionova M, Zheleva A, Alexiev C, Halacheva K, Todorov D. Cytotoxicity on L1210 leukemic cells of beta-amanitinconcanavalin A and phallacidin-concanavalin A conjugates. Toxicon 1990; 28: 1360-1363.

23. Zhelev Z, Zheleva A, Halacheva K. Preparation of a beta-amanitinconcanavalin A conjugate of low toxicity. Toxicon 1987; 25: 981987.
24. Kaya E, Karahan S, Yaykaşlı KO, Bayram R, Sarıtaş A. Purification of high purity alpha amanitin using preparative HPLC method. Konuralp Med J 2012; 4: 35-41.

25. Kaya E, Yaykaşlı KO, Karahan S, Bayram R, Sarıtaş A, Yaykaşlı E. Production of high purity beta amanitin. Düzce Tip Dergisi 2012; 14: 48-53.

26. Magdalan J, Ostrowska A, Piotrowska A, Gomułkiewicz A, Szeląg A, Dziędgiel P. Comparative antidotal efficacy of benzylpenicillin, ceftazidime and rifamycin in cultured human hepatocytes intoxicated with a-amanitin. Arch Toxicol 2009; 83: 1091-1096.

27. Savory J, Pu PH, Sunderman FW Jr. A biuret method for determination of protein in normal urine. Clin Chem 1968; 14: $1160-1171$

28. Wieland T, Faulstich H. Fifty years of amanitin. Experientia 1991; 47: 1186-1193.

29. Andera L, Wasylyk B. Transcription abnormalities potentiate apoptosis of normal human fibroblasts. Mol Med 1997; 3: 852-863.

30. Arima Y, Nitta M, Kuninaka S, Zhang D, Fujiwara T, Taya Y, Nakao M, Saya H. Transcriptional blockade induces p53-dependent apoptosis associated with translocation of p53 to mitochondria. J Biol Chem 2005; 280: 19166-19176.

31. Gartel AL. Transcriptional inhibitors, $\mathrm{p} 53$ and apoptosis. Biochim Biophys Acta 2008; 1786: 83-86.

32. Zheleva A, Benov L, Zhelev Z. Amanitin-induced toxicity may involve free radicals. Toxicon 1990; 28: 169.

33. Ishihara Y, Shiba D, Shimamoto N. Primary hepatocyte apoptosis is unlikely to relate to caspase-3 activity under sustained endogenous oxidative stress. Free Radic Res 2005; 39: 163-173.

34. Zheleva A, Tolekova A, Zhelev M, Uzunova V, Platikanova M, Gadzheva V. Free radical reactions might contribute to severe alpha amanitin hepatotoxicity - a hypothesis. Med Hypotheses 2007; 69: 361-367.

35. Qu LY, Jiang YL, Tang XW. Effect of DRB/alpha-amanitin on localization of Nrf2 in A549 cells. Zhejiang Da Xue Xue Bao Yi Xue Ban 2010; 39: 24-29 (article in Chinese with English abstract).

36. Leist M, Gantner F, Naumann H, Bluethmann H, Vogt K, BrigeliusFlohé R, Nicotera P, Volk HD, Wendel A. Tumor necrosis factorinduced apoptosis during the poisoning of mice with hepatotoxins. Gastroenterology 1997; 112: 923-934.

37. El-Bahay C, Gerber E, Horbach M, Tran-Thi QH, Röhrdanz E, Kahl R. Influence of tumor necrosis factor-alpha and silibin on the cytotoxic action of alpha-amanitin in rat hepatocyte culture. Toxicol Appl Pharmacol 1999; 158: 253-260.

38. Hallen HE, Luo H, Scott-Craig JS, Walton JD. Gene family encoding the major toxins of lethal Amanita mushrooms. Proc Natl Acad Sci USA 2007; 104: 19,097-19,101.

39. Wieland T, Faulstich H. Amatoxins, phallotoxins, phallolysin, and antamanide: the biologically active components of poisonous Amanita mushrooms. CRC Crit Rev Biochem 1978; 5: 185-260.

40. Faulstich H, Talas A, Wellhöner HH. Toxicokinetics of labeled amatoxins in the dog. Arch Toxicol 1985; 56: 190-194.

41. Riede I. Tumor therapy with Amanita phalloides (death cap): stabilization of B-cell chronic lymphatic leukemia. J Altern Complement Med 2010; 16: 1129-1132. 